\title{
Autoimmunity to La (SS-B) in vitro is related to HLA-DR3 in healthy subjects
}

\author{
PATRICK J W VENABLES, SHIRLEY RIGBY, PAT A MUMFORD, \\ JOHN MARKWICK, AND RAVINDER N MAINI
}

From the Division of Clinical Immunology, Kennedy Institute of Rheumatology, Hammersmith, London; and the Department of Immunology of Rheumatic Diseases and Tissue Typing, Charing Cross Hospital Medical School, London

SUMMARY In patients with Sjögren's syndrome $50-90 \%$ of those who have anti-La (SS-B) in their serum are HLA-DR3 positive. To investigate the relation between DR3 and anti-La N antibody production 18 healthy subjects were divided into nine pairs, each matched for age and $\mathrm{O}$ sex, containing one DR3 positive individual and one with a different DR type. Peripheral blood $\overrightarrow{-}$ mononuclear cells from each pair were cultured with varying doses of pokeweed mitogen and supernatants from nine day cultures assayed for antibodies to La, nRNP/Sm, and DNA by enzyme linked immunosorbent assay (ELISA) using purified antigens. In each case peak anti-La₹ secretion was greater in the DR3 positive subject than in the matched DR3 negative individual; in $\vec{\oplus}$ contrast, there was no consistent difference in levels of anti-DNA or anti-nRNP/Sm secretion. $\infty$ This specificity of enhanced autoantibody response in healthy individuals after polyclonalס activation suggests that anti-La production may be under the control of genes linked to DR3.

Key words: Sjögren's syndrome, tissue typing, DR3, La.

A role for genetic factors in autoimmunity is suggested by associations between certain HLA antigens and patterns of autoimmune disease. The link between DR4 and rheumatoid arthritis is now well established. ${ }^{1}$ More recent studies have shown that this tissue type is further increased in patients whose sera contain high titres of rheumatoid factors. $^{2-4}$ In primary Sjögren's syndrome there is an increased prevalence of both HLA-B8 and DR3. ${ }^{5-7}$ Several studies have shown an increased prevalence of HLA-B8, DR3 in patients whose sera contain antibodies to the ribonucleoproteins Ro (SS-A) and La (SS-B), ${ }^{8-13}$ both in patients with Sjögren's syndrome $^{8-10}$ and in those with systemic lupus erythematosus (SLE) ${ }^{11-13}$ Also, in SLE an association between DR2 and anti-DNA antibodies has been reported. ${ }^{12} 13$

These studies suggest that HLA antigens may determine the specificity of certain autoantibodies, the strongest link being between DR3 and anti-La.

Accepted for publication 4 Junc 1987.

Correspondence to Dr P J W Venables. Division of Clinical Immunology, Kennedy Institute of Rheumatology. 6 Butc Gardens. Hammersmith. London W6 7DW.
The prevalence of HLA-B8, DR3 in patients with Sjögren's syndrome who have this antibody has been reported to be over $90 \% .{ }^{6}{ }^{8}$ We have purified La by affinity chromatography and have develope an enzyme linked immunosorbent assay (ELISA ğ sufficiently sensitive to detect and measure anti-Lج. secretion by in vitro pokeweed mitogen (PWM $\$$ stimulated normal peripheral blood mononuclea cells (PBMs) from patients with Sjögren'S syndrome. ${ }^{14}$ More recently we have detected anti $>$ La secreted by PBMs from normal subjects. ${ }^{15}$ The amount of antibody was variable, but in two out of seven cases the peak anti-La secretion approached the levels secreted by PBMs from patients.

The purpose of this study was to see whethet lymphocytes from DR3 positive healthy individual secreted more anti-La than matched DR3 negative controls. This approach allowed us to examine the possibility that the repertoire of the potentiaf autoantibody response of healthy people was undero genetic control.

\section{Subjects and methods}

Eighteen healthy subjects (age range 23-39, eigh(웅 
male and 10 female) were selected from the staff at Charing Cross Hospital and the London Hospital tissue typing laboratories to include nine DR3 positive (mean age 29.2) and nine DR3 negative (mean age 31.5 ) individuals, typed as previously described. ${ }^{4}$ Eight of the nine DR3 positive subjects, but none of the DR3 negative subjects, were also HLA-B8 positive (Table 1).

The subjects were divided into nine pairs (A-I) matched for sex and age, each pair being set up for culture and harvested at the same time using the same reagents. Peripheral blood mononuclear cells from $30 \mathrm{ml}$ of heparinised blood were separated by Ficol-Hypaque and cultured in triplicate at a final concentration of $10^{6} \mathrm{cells} / \mathrm{ml}$ as previously described, ${ }^{15}$ except that $1 \mathrm{ml}$ (as opposed to $2.5 \mathrm{ml}$ ) cultures were used unstimulated (in RPMI 1640 containing $10 \%$ human $\mathrm{AB}$ serum) and with added doubling dilutions of PWM (Gibco, Paisley, UK) from $0.625 \mu \mathrm{g} / \mathrm{ml}$ to $40 \mu \mathrm{g} / \mathrm{ml}$. Two batches of $A B$ serum, which we have termed $A B 1$ and $A B 2$, from Flow Laboratories, Irvine, UK, were used. PBMs from six subjects (three pairs) were cultured in $A B 1$ and PBMs from six pairs in AB 2. Supernatants were harvested after nine days and assayed for IgG antibody by an ELISA using purified antigens as previously described. ${ }^{15}$ La (SS-B) antigen and
$\mathrm{nRNP} / \mathrm{Sm}$ complex were purified by affinity chromatography from ammonium sulphate fractions of rabbit thymus powder and double stranded DNA from calf thymus DNA as previously described. ${ }^{14-16}$ All the culture supernatants were assayed in triplicate for anti-La, and supernatants from eight pairs were tested for anti-nRNP/Sm and anti-double stranded DNA. In each case secreted antibody was measured by comparison with a standard curve of dilutions of a reference serum, one unit corresponding to the binding of a 1 in 128000 dilution of the serum.

Differences in peak antibody secretion between the individuals in each matched pair were examined statistically by two tailed binomial testing.

\section{Results}

When the DR3 positive subjects and those with other DR types were considered as two groups the geometric mean levels of peak anti-La secretion in the DR3 positive individuals were double those of the DR3 negative group (Table 2). There were no differences in the mean levels of anti-nRNP/Sm or anti-double stranded DNA. Both DR3 positive and negative subjects responded to PWM with a similar dose response curve (Fig. 1). The median peak for

Table 1 HLA tissue types of nine pairs of healthy subjects and peak antibody levels secreted by their peripheral blood mononuclear cells

\begin{tabular}{|c|c|c|c|c|c|c|c|c|c|}
\hline \multirow[t]{2}{*}{ Pair } & \multirow[t]{2}{*}{ Age } & \multirow[t]{2}{*}{ Sex } & \multicolumn{4}{|c|}{ HLA locus } & \multicolumn{3}{|c|}{ Peak antibody levels (U/ml/ to: } \\
\hline & & & $A$ & $B$ & $C$ & $D$ & $L a$ & $n R N P / S m$ & $D N A$ \\
\hline A & $\begin{array}{l}24 \\
26\end{array}$ & $\begin{array}{l}\mathbf{M} \\
\mathbf{M}\end{array}$ & $\begin{array}{l}1,25 \\
1,31\end{array}$ & $\begin{array}{c}8, w 62 \\
51,7\end{array}$ & $\begin{array}{l}\text { w7,w3 } \\
\text { w7,- }\end{array}$ & $\begin{array}{l}3,4 \\
1,4\end{array}$ & $\begin{array}{l}92 \\
12\end{array}$ & $\begin{array}{l}11 \\
9.4\end{array}$ & $\begin{array}{l}0.6 \\
0.6\end{array}$ \\
\hline B & $\begin{array}{l}29 \\
39\end{array}$ & $\begin{array}{l}F \\
F\end{array}$ & $\begin{array}{l}2,26 \\
1,23\end{array}$ & $\begin{array}{r}8,27 \\
14,27\end{array}$ & $\begin{array}{l}\mathrm{w4}, \mathrm{w6} \\
-\end{array}$ & $\begin{array}{l}3,- \\
4, w 6\end{array}$ & $\begin{array}{l}11 \\
4 \cdot 4\end{array}$ & $\begin{array}{r}4.4 \\
55 \cdot 7\end{array}$ & $\begin{array}{l}4.9 \\
5 \cdot 4\end{array}$ \\
\hline C & $\begin{array}{l}27 \\
37\end{array}$ & $\begin{array}{l}\mathbf{M} \\
\mathbf{M}\end{array}$ & $\begin{array}{c}1,3 \\
24,28\end{array}$ & $\begin{array}{l}\text { 8,w58 } \\
27,35\end{array}$ & $\begin{array}{l}\text { w7,- } \\
\text { w4,- }\end{array}$ & $\begin{array}{l}3, w 12 \\
1,5\end{array}$ & $\begin{array}{c}18 \\
8 \cdot 3\end{array}$ & $\begin{array}{r}14.5 \\
5.9\end{array}$ & $\begin{array}{l}4 \cdot 2 \\
5 \cdot 0\end{array}$ \\
\hline D & $\begin{array}{l}39 \\
38\end{array}$ & $\begin{array}{l}F \\
F\end{array}$ & $\begin{array}{r}3,- \\
29,-\end{array}$ & $\begin{array}{c}8, w 47 \\
44,-\end{array}$ & $\begin{array}{l}\text { w6,- } \\
\text { w5,- }\end{array}$ & $\begin{array}{l}3,4 \\
7,-\end{array}$ & $\begin{array}{l}18 \\
11\end{array}$ & $\begin{array}{l}3 \cdot 0 \\
10\end{array}$ & $\begin{array}{l}6 \cdot 6 \\
3 \cdot 8\end{array}$ \\
\hline E & $\begin{array}{l}23 \\
29\end{array}$ & $\begin{array}{l}\mathbf{F} \\
\mathbf{F}\end{array}$ & $\begin{array}{l}1,2 \\
2,29\end{array}$ & $\begin{array}{r}8, w 61 \\
44, w 60\end{array}$ & $\begin{array}{l}w 2, w 7 \\
w 3, w 4\end{array}$ & $\begin{array}{l}3, w 11 \\
7, w 9\end{array}$ & $\begin{array}{l}11 \\
7 \cdot 0\end{array}$ & $\begin{array}{l}4 \cdot 8 \\
6 \cdot 0\end{array}$ & $\begin{array}{l}\text { ND } \\
\text { ND }\end{array}$ \\
\hline $\mathbf{F}$ & $\begin{array}{l}32 \\
28\end{array}$ & $\begin{array}{l}F \\
F\end{array}$ & $\begin{array}{l}1,2 \\
2,24\end{array}$ & $\begin{array}{r}13,27 \\
7,37\end{array}$ & $\begin{array}{l}w 2, w 6 \\
w 6, w 7\end{array}$ & $\begin{array}{l}3,4 \\
1, w 6\end{array}$ & $\begin{array}{l}7 \cdot 5 \\
5 \cdot 0\end{array}$ & $\begin{array}{l}\text { ND } \\
\text { ND }\end{array}$ & $\begin{array}{l}20 \\
17\end{array}$ \\
\hline G & $\begin{array}{l}29 \\
33\end{array}$ & $\begin{array}{l}\mathbf{F} \\
\mathbf{F}\end{array}$ & $\begin{array}{l}3,32 \\
1,2\end{array}$ & $\begin{array}{r}8,35 \\
14,35\end{array}$ & $\begin{array}{l}\text { w4,- } \\
\text { w6,- }\end{array}$ & $\begin{array}{l}3,1 \\
1,5\end{array}$ & $\begin{array}{r}110 \\
80\end{array}$ & $\begin{array}{l}14 \\
12\end{array}$ & $\begin{array}{l}13 \\
7 \cdot 3\end{array}$ \\
\hline $\mathbf{H}$ & $\begin{array}{l}34 \\
29\end{array}$ & $\begin{array}{l}\mathbf{M} \\
\mathbf{M}\end{array}$ & $\begin{array}{l}1,32 \\
3,31\end{array}$ & $\begin{array}{r}8,38 \\
44,18\end{array}$ & $\overline{w 4, w 5}$ & $\begin{array}{l}3, w 6 \\
7,8\end{array}$ & $\begin{array}{l}155 \\
120\end{array}$ & $\begin{array}{l}4 \cdot 6 \\
5 \cdot 8\end{array}$ & $\begin{array}{l}8 \cdot 4 \\
5 \cdot 7\end{array}$ \\
\hline $\mathbf{I}$ & $\begin{array}{l}27 \\
24\end{array}$ & $\begin{array}{l}\mathbf{M} \\
\mathbf{M}\end{array}$ & $\begin{array}{l}1,25 \\
2,44\end{array}$ & $\begin{array}{l}\text { 8,w62 } \\
\text { w62,- }\end{array}$ & $\begin{array}{l}\text { w7,w3 } \\
\text { w3,- }\end{array}$ & $\begin{array}{l}3,4 \\
4,-\end{array}$ & $\begin{array}{l}6 \cdot 2 \\
5 \cdot 1\end{array}$ & $\begin{array}{l}20 \\
10\end{array}$ & $\begin{array}{l}3 \cdot 5 \\
6 \cdot 6\end{array}$ \\
\hline
\end{tabular}


anti-La secretion was $5 \mu \mathrm{g} / \mathrm{ml}$ in both the DR3 positive and DR3 negative groups. There was considerable variation in the amount of anti-La antibody secreted between individuals and between experiments, with peak values varying from 4.4 units to $155 \mathrm{U} / \mathrm{ml}$ (Table 1) (approximately 1:35000 to $1: 1000$ of the levels found in pathological sera), accounting for the wide confidence limits shown in Table 2. The variability was too great for valid statistical testing of the data analysed in group form.

Reproducibility was assessed by repeating the assays on different occasions for two pairs of subjects, those whose cells gave the highest peak

Table 2 Geometric mean peak antibody secretion (U/ml) in response to pokeweed mitogen ( $P W M$ )

\begin{tabular}{lll}
\hline & $\begin{array}{l}D R 3 \\
(n=9)\end{array}$ & $\begin{array}{l}\text { Non-DR3 } \\
(n=9)\end{array}$ \\
\hline Anti-La & $24 \cdot 2(7-83)^{*}$ & $12 \cdot 6(4-43)$ \\
Anti-nRNP/Sm & $9 \cdot 4(5-20)$ & $10 \cdot 3(5-22)$ \\
Anti-dsDNA & $7 \cdot 4(4-14)$ & $6 \cdot 7(4-11)$ \\
$\begin{array}{l}\text { Median dose PWM for } \\
\text { peak anti-La }(\mu \mathrm{g} / \mathrm{ml})\end{array}$ & 5.0 & \\
\hline
\end{tabular}

${ }^{*}$ Numbers in brackets represent the confidence limits for each group.
anti-La antibody levels and those with the lowes? (Table 3). In the first experiment, using pair $\mathrm{D}$, anti La levels were low, though the peak secretion os anti-La by the DR3 positive subject was $68 \%$ more than that of the matched DR3 negative contro (ratio 1.68). On repeat, peak levels were higher in both subjects, though the ratio between $D R{ }^{D}$ positive and negative was similar (1.64). Pair secreted very high levels of anti-La in the first experiment, and cells from the DR3 positive subjec? secreted only marginally more specific antibod (ratio 1.29). On repeat, peak levels were lower, bue the ratio was again marginal, on this occasion $1.04 \frac{0}{0}$

Table 3 Between experiment variation in peak anti-La antibody levels secreted by PBMs from normal subjects

\begin{tabular}{|c|c|c|}
\hline & Expt 1 & Expt 2 \\
\hline \multicolumn{3}{|l|}{ Pair D } \\
\hline DR3 & $4 \cdot 2$ & 18 \\
\hline Non-DR3 & $2 \cdot 5$ & 11 \\
\hline Ratio & $1 \cdot 68$ & $1 \cdot 64$ \\
\hline
\end{tabular}

Pair $\mathbf{H}$

$\begin{array}{lll}\text { DR3 } & 155 & 25 \\ \text { Non-DR3 } & 120 & 24\end{array}$

Ratio

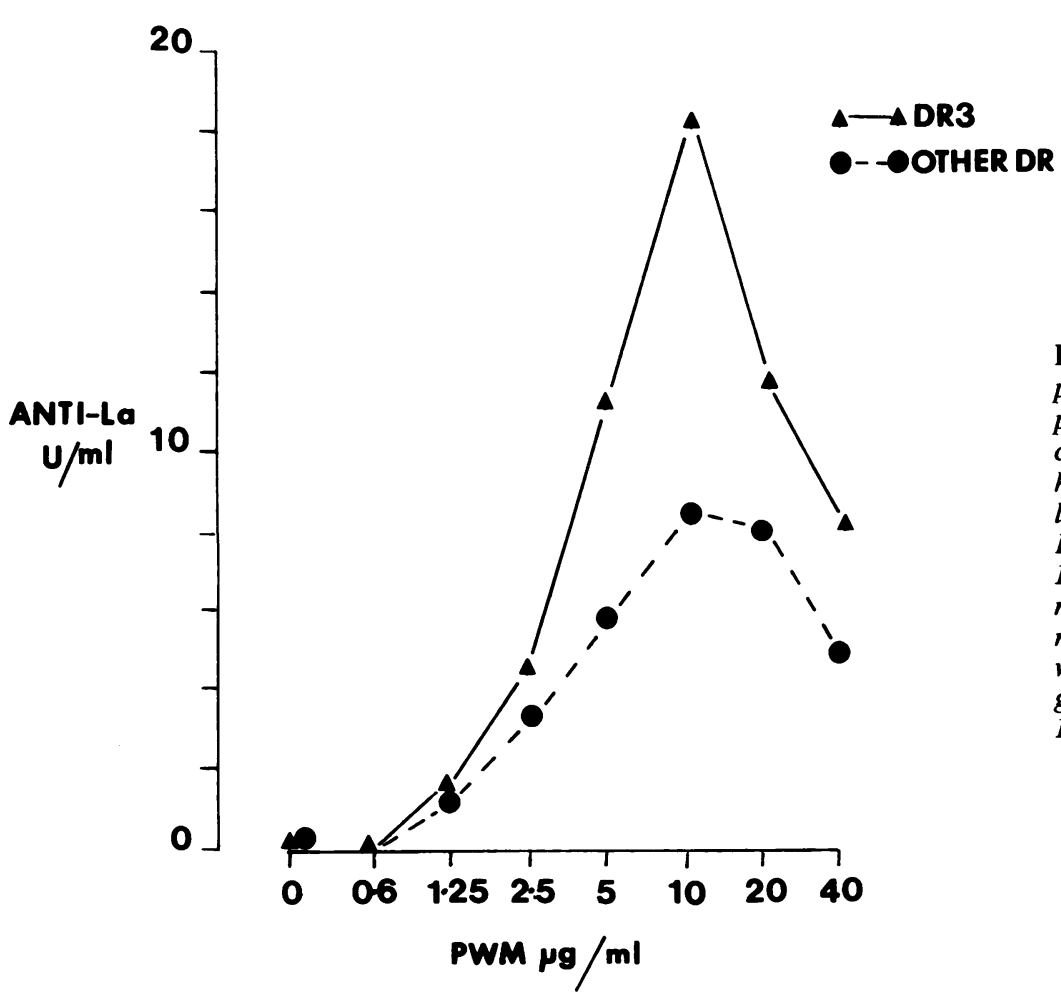

Fig. 1 Dose response curves to pokeweed mitogen (PWM) of peripheral blood mononuclear cells from a matched pair of healthy subjects (pair $C$ ). The peak level of anti-La in cells from the $D R 3$ positive individual was $18 \mathrm{U} / \mathrm{ml}$ and from the DR3 negative subject $8.3 \mathrm{U} / \mathrm{ml}$. The ratio between the two peak levels was $2 \cdot 16$ and the dose of PWM giving the peak response was $10 \mu \mathrm{g} / \mathrm{ml}$ in both cases. 
This showed that the between experiment variability of absolute levels of anti-La was large, though for these four subjects the reproducibility of the ratio was relatively good.

Because of between experiment variations the use of matched pairs, cultured and assayed at the same time with the same reagents, was the basis of our experimental design. Under these conditions peak anti-La antibody secretion by lymphocytes from DR3 positive normal individuals was consistently greater than with their matched controls (Fig. 2) $(p=0.004)$. This varied from a slight increase $(22 \%$ more than the matched control) to more than $600 \%$, i.e., seven times as much specific antibody. There were no consistent differences in the amount of anti$\mathrm{nRNP} / \mathrm{Sm}$ or anti-DNA antibody. This suggested that among the three autoantigens tested there was a specific increase in anti-La secretion in response to polyclonal activation of lymphocytes from DR3 positive subjects.

\section{Discussion}

Our study has confirmed previous reports that autoantibodies to cellular antigens are secreted by polyclonally activated lymphocytes from healthy subjects in vitro. ${ }^{1517} 18 \mathrm{In}$ addition, we have shown an effect of DR3, or genes closely linked to it, on anti-La (SS-B) secretion, which may reflect the relation between DR3 and Sjögren's syndrome. We have also been able to show specificity as the DR3 positive subjects did not show an increase in the production of antibodies to $\mathrm{nRNP} / \mathrm{Sm}$ or double stranded DNA.

Two features of in vitro investigation of autoantibody secretion influenced the design of this study:
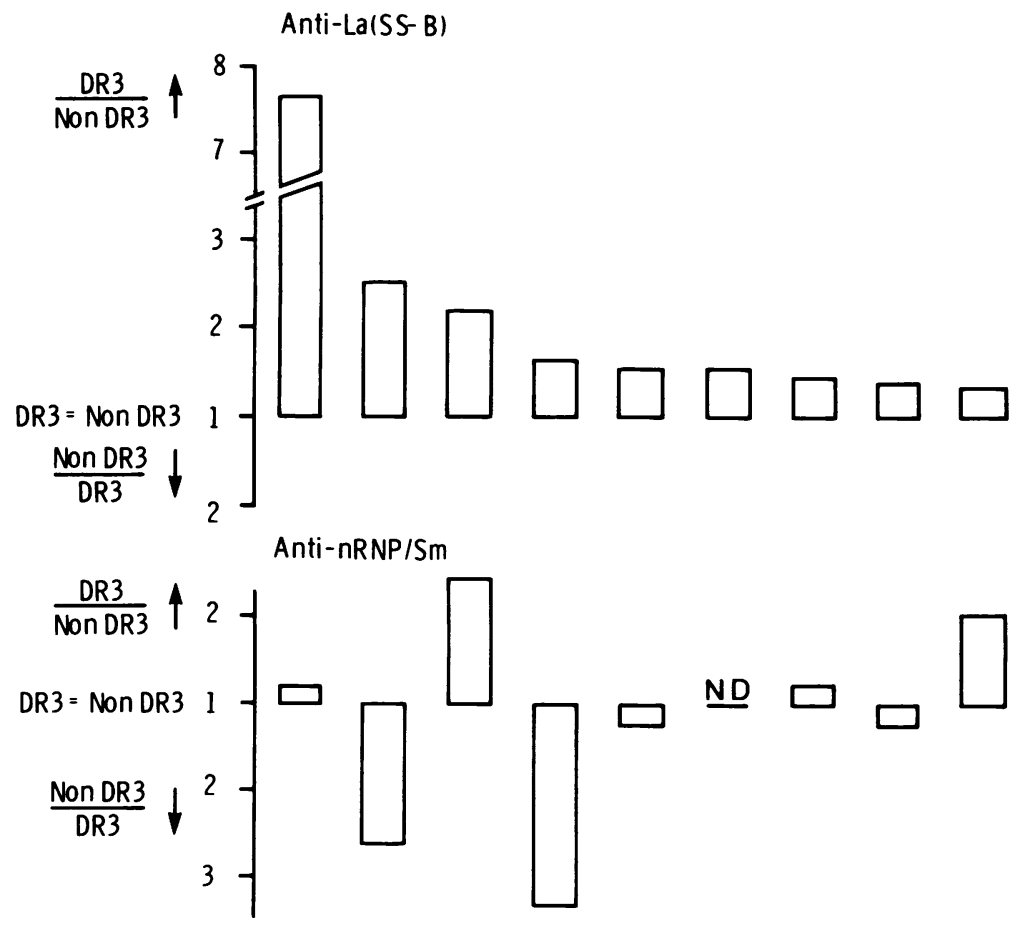

Fig. 2 Ratios of anti-La, anti-nRNP/Sm, and anti-DNA secretion by peripheral blood mononuclear cells from each of nine pairs $(A-I)$ of healthy subjects. An upward deflection of the histogram indicates that the DR3 positive subject has secreted more antibody than the matched control. This occurred in all DR3 positive cases for antibody to $\mathrm{La}$ $(S S-B)(p=0.004)$, but not for antibodies to $n R N P / S m(p=0.64)$ or DNA $(p=0.5)$.

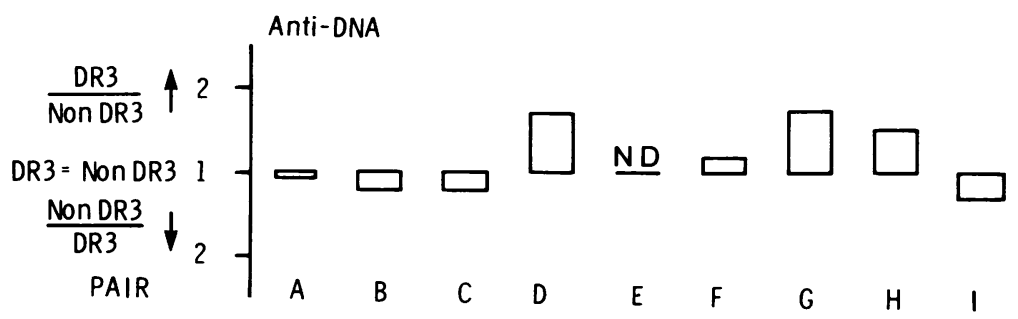


the need for highly purified antigens and experiment to experiment variability in cell culture. An ELISA for detection of anti-La has been in use in our laboratory for four years and its antigen specificity proved by the purity of the antigen on gel electrophoresis, ${ }^{14}{ }^{19}$ by studies of clinical sera, ${ }^{14}$ by the isolation of monoclonal anti-La antibodies, ${ }^{20}$ and by the generation of anti-La anti-idiotypes. ${ }^{21}$ We have also previously investigated the specificity of anti-La antibodies secreted in culture by healthy subjects. ${ }^{15}$ We showed that antibodies binding to the La ELISA plates were not binding to the plastic of the plate itself or to the casein which had been used to block it and demonstrated antigen specificity by adsorption experiments with La (SS-B) and nRNP/ $\mathrm{Sm}$ antigens on ELISA plates. In our present study the use of $n R N P / S m$ complex as a control provided further evidence of the specificity of the binding to La. Both $\mathrm{La}$ and $\mathrm{nRNP} / \mathrm{Sm}$ are ribonucleoprotein complexes which contain several species of RNA. If the binding to the La antigen were due to anti-RNA antibodies or to some non-specific charge-charge interaction one would expect to see similar binding to $\mathrm{nRNP} / \mathrm{Sm}$. Levels of antibodies secreted to the two antigens were quite unrelated in different individuals, however, and there was no evidence of increased secretion of anti-nRNP/Sm in the DR3 positive subjects. The similarity in the way that the antigens were prepared from the same substrate argues against the possibility of binding to small quantities (not detectable by electrophoresis) of copurifying cellular antigens present in the rabbit thymus.

Experimental variability in cell culture has been reported in previous studies of healthy subjects, ${ }^{22}$ and in our data this is apparent not only in the wide range of values seen in the groups as a whole but also in the same individuals when tested on different occasions. The hypothesis which this study set out to examine-namely, the contribution of DR3 to the quantity of anti-La antibody secretion, was shown by the reproducibility of the ratio of peak antibody secretion in two pairs tested on two occasions. By conducting the experiments and analysing the data with matched pairs we were able to show a significant relative increase in anti-La secretion in association with DR3, which otherwise would have been partly obscured by between experiment variation.

Several previous investigators have noted abnormalities in immune regulation in association with HLA-DR3 or HLA-B8, the antigen in linkage disequilibrium with it. ${ }^{22-26}$ Defects in $\mathrm{T}$ cells have included decreased responses in B8 positive normal subjects to phytohaemagglutinin 2223 and to concanavalin $A, 222425$ and impaired lymphocyte responses to phytohaemagglutinin in B8 positive patients with Sjögren's syndrome. ${ }^{26}$ Two studies? also reported increased numbers of IgG secreting $B_{\rightarrow}$ : cells in B8 positive individuals, ${ }^{24}{ }^{25}$ and another found evidence of defective $\mathrm{Fc}$ receptor function. ${ }^{23}$

All these studies suggest defects, either lack of to cell control or increased activation of B cells, whichs may account for mechanisms by which HLA-B尺 could be a risk factor in the development of autoimmunity. The association between autoim =munity and HLA-B8, DR3 cannot be regarded as universal, however. Although the haplotype is common in patients with many of the organ specifie autoimmune diseases, there is evidence that in non organ specific autoimmunity HLA-B8, DR3 iss specifically associated with antibodies to La (SS-B) $)^{2}$ and to the closely related antigen Ro (SS-A) both in Sjögren's syndrome ${ }^{6910}$ and SLE, ${ }^{11-13}$ whereas antibodies to DNA are associated with DR2, ${ }^{12} 13$ and no clear HLA associations have been shown $\vec{e}$ with anti-nRNP/Sm. These disease associations appear to be reflected in the autoantibody response्ध in healthy subjects in vitro. The fact that the antibodies were of IgG class suggests the participa $\vec{\bullet}$ tion of $T$ cells, and the production of anti-La woul $\mathbb{S}_{0}^{\circ}$ certainly be compatible with the $T$ cell defect 8 associated with DR3 already described. ${ }^{22-26}$ The lack of an apparent effect of DR3 on the production of anti-nRNP/Sm or DNA suggests that the defect is in the control of anti-La but not in the control of tho other two antibody specificities examined. This provides some evidence to suggest that the DR associated $T$ cell defect may be restricted to auto antibodies associated with DR3. If this were the case one would predict that DR3 positive normal cells would also secrete higher levels of antibodies tơ organ specific autoantigens.

It is possible that our experimental protocol was examining an antigen driven system. The La (SS-B $\not$ antigen is present in the nuclei of normal lympho cytes. After activation we have shown that io increases in quantity and moves to the nucleolus an cytoplasm. ${ }^{20}$ Although La has not yet been demono strated on the surface of cells, other nuclear antigen such as nRNP and DNA have. ${ }^{27}$ It is possible thaP La could be presented to responding cells on the surface of activated or virus infected cells. Alterna tively, the antigen could be released by lysis of nono viable cells, processed, and presented by maغ rophages. Whatever the mechanism, the antige would be present on cells expressing HLA class IIS? and the nature of the class II molecule (i.e., DR3) could influence the nature of the antibody response

The detection of anti-La in the supernatants fror the cell cultures suggests that there are many B cello bearing immunoglobulin with anti-La activity i healthy subjects, and that in a proportion of sucti 
people the antibody should be detectable in their sera. Harley et al demonstrated anti-La antibodies in $12.5 \%$ of normal sera and argued that antigen specificity was shown by their ability to inhibit such binding with free antigen. ${ }^{10}$ Their study does not disagree with our previous report ${ }^{14}$ in which we described five out of $45(11 \%)$ normal sera binding to $\mathrm{La}$ at dilutions of $1: 1000$ above $5 \mathrm{U} / \mathrm{ml}$, approximately $1 \%$ of the levels found in pathological sera. These sera did not form precipitins on immunodiffusion nor did they give the characteristic speckled staining pattern on immunofluorescence. In our experience, normal sera do not react with the La specific 45 kilodalton polypeptide on immunoblotting. ${ }^{28}$ We have also shown that idiotypes near the antigen binding sites on anti-La antibodies are private and are not detectable on IgG from healthy people. ${ }^{21}$ One explanation for this paradox is that the anti-La antibodies generated by polyclonal activation are of low affinity and detectable by ELISA but not by other techniques. Possible mechanisms for the development of anti-La antibodies in Sjögren's syndrome could include affinity maturation of antibodies in response to constant exposure to autoantigen. Factors underlying these mechanisms remain unknown, though our study and previous work suggest that a specific $\mathrm{T}$ cell defect associated with DR3 is important.

We would like to thank all the subjects who donated blood for these experiments, including Dr Bill Ollier (London Hospital) who also typed three of the volunteers. We would also like to thank $\mathrm{Dr}$ MacRea (Charing Cross Hospital) for statistical advice. Miss Shirley Rigby performed part of the work as an intercalated BSc project and was partly supported by a short term grant from the Nuffield Foundation. The other authors were supported by grants from the Arthritis and Rheumatism Council of Great Britain.

\section{References}

1 Stastny P. Association of the B-cell alloantigen DR4 with rheumatoid arthritis. New Engl J Med 1980; 298: 869.

2 Jaraquemada D, Pachoula-Papasteriadis C, Festenstein $\mathrm{H}$, et al. HLA-D and DR determinants in rheumatoid arthritis. Transplant Proc 1979; 11: 1306.

3 Stastny P. Joint report on rheumatoid arthritis. In: Terasaki P I, ed. Histocompatibility testing 1980. Los Angeles: UCLA Tissue Typing Lab, 1980: 681 .

4 Ollier W, Venables P J W, Mumford P A, et al. HLA antigen associations with extra articular rheumatoid arthritis. Tissue Antigens 1984; 24: 279-91.

5 Moutsopoulos H M. Chused T M. B lymphocyte antigens in Sjögren's syndrome. Science 1978; 199: 1441-2.

6 Whittingham S, Mackay I R, Tait B D. Autoantibodies to small ribonucleoproteins. A strong association between anti-SS-B (La), HLA B8 and Sjögren's syndrome. Aust NZ J Med 1983: 13: $565-70$.

7 Chused T M, Kassan S S, Opelz G. Moutsopoulos H M. Terasaki P I. Sjögren's syndrome associated with HLA B8. New Engl J Med 1977: 296: 895-902.

8 Wilson R W, Provost T T, Bias W B, et al. Sjögren's syndrome. Influence of multiple HLA-D region alloantigens on clinical and serologic expression. Arthritis Rheum 1984: 27: 1245-53.
9 Manthorpe R. Teppo A M. Bendixen G. Wegelius O. Antibodies to SS-B in chronic inflammatory connective tissue diseases: relationship to HLA-Dw2 and Dw3 antigens in primary Sjögren's syndrome. Arthritis Rheum 1982; 25: 662-7.

10 Harley J B. Alexander E L. Bias W B. et al. Anti-Ro (SS-A) and anti-La (SS-B) in patients with Sjögren's syndrome. Arthritis Rheum 1986; 29: 196-206.

11 Bell D A. Maddison P J. Serologic subsets in systemic lupus erythematosus: an examination of autoantibodies in relation to clinical features of disease and HLA antigens. Arthritis Rheum 1980; 23: 1268-73.

12 Alvarellos A. Ahearn J M. Provost T T, et al. Relationship of HLA-DR and MT antigens to autoantibody expression in SLE. Arthritis Rheum 1983: 26: 1533-5.

13 Arnett F C, Reveille J D, Wilson R W, Provost T T. Bias W B. SLE: current state of the genetic hypothesis. Semin Arthritis Rheum 1984; 14: 24-35.

14 Venables P J W. Charles P J. Buchanan R R C. et al. Quantitation of isotypes of anti-SS-B antibodies by ELISA and Farr assays using affinity purified antigen. Arthritis Rheum 1983; 26: 146-55.

15 Mumford P A. Room G R W, Venables P J W, Maini R N. IgG antibodies to SS-B (La), RNP/Sm and DNA are produced by normal lymphocytes in culture. Rheumatol Int 1985; 5: 109-12.

16 Buchanan R R C, Venables P J W, Morgan A. Staines N A. Smith P R, Maini R N. Separation of two molecular species of the $\mathrm{Sm}$ antigen by affinity chromatography with murine monoclonal and human antinuclear antibodies. Clin Exp Immunol 1983: 51: 8-16.

17 Bankhurst A D. Torigiani G. Allison A C. Lymphocytes binding to thyroglobulin in healthy people and its relevance to tolerance for autoantigens. Lancet 1973; i: 226-30.

18 Bankhurst A D, Williams R C. Identification of DNA binding lymphocytes in patients with systemic lupus erythematosus. J Clin Invest 1975: 56: 1378-85.

19 Venables P J W, Smith P R. Maini R N. Purification and characterisation of the Sjögren's syndrome $A$ and $B$ antigens. Clin Exp Immunol 1983; 54: 731-8.

20 Smith P R, Williams D G, Venables P J W, Maini R N. Monoclonal antibodies to the Sjögren's syndrome associated antigen SS-B (La). J Immunol Methods 1985; 77: 63-76.

21 Horsfall A C, Venables P J W, Mumford P A, Maini R N. Restricted idiotypes on antibodies to the La (SS-B) antigen. Clin Exp Immunol 1986; 63: 393-401.

22 McCombs C C, Michalski J P. Lymphocyte abnormality associated with HLA-B8 in healthy young adults. $J$ Exp Med 1982; 156: 936-41.

23 Greenburg L J, Yunis E J. Histocompatibility determinants, immune responsiveness, and ageing in man. Fed Proc 1978; 37: 1258-61.

24 Ambinder J M, Chiorazzi N, Gibofski A, Fotino M, Kunkel H J. Special characteristics of cellular immune function in normal individuals of the HLA DR3 type. Clin Immunol Immunopathol 1982: 23: 269-74.

25 Lawley T J. Hall R P. Fauchi A S, Katz S I, Hamburger M I. Frank M M. Defective Fc receptor functions associated with the HLA-B8/DRw3 haplotype. N Engl J Med 1981; 304: 185-92.

26 Michaiski J P. McCombs C, Fye K H, Daniels T E, Terasaki P I, Talal N. Impaired lymphocyte response in patients with Sjögren's syndrome associated with HLA-B8. J Lab Clin Immunol 1978: 1: 25-9.

27 LeFeber W P, Norris D A, Ryan S R. et al. Ultraviolet light induces binding of antibodies to selected nuclear antigens on cultured human keratinocytes. J Clin Invest 1984; 74: 1545-51.

28 Williams D G. Stocks M R, Charles P J, Maini R N. Antibodies to La, Jo-1, nRNP and Sm detected by multi-track immunoblotting using a novel filter holder: a comparative study with counterimmunoelectrophoresis using sera from patients with systemic lupus erythematosus and Sjögren's syndrome. J Immunol Methods 1986; 91: 65-73. 